Commentaries on judicial decisions $\frac{\text { Studia luridica Lublinensia vol. XXX, 4, } 2021}{\text { DOI: 10.17951/sil.2021.30.4.639-654 }}$

\author{
Jarosław Dudzik
}

Maria Curie-Skłodowska University in Lublin, Poland

ORCID: 0000-0002-2126-8650

jaroslaw.dudzik@umcs.pl

\title{
Ograniczenia importu równoległego produktów leczniczych. Uwagi na tle wyroku Trybunału Sprawiedliwości Unii Europejskiej w sprawie C-602/19 Kohlpharma
}

\author{
Limitations on Parallel Import of Medicinal Products: Comments in \\ the Context of the Judgement of the Court of Justice of the European \\ Union in Case C-602/19 Kohlpharma
}

\section{ABSTRAKT}

Wyrok w sprawie C-602/19 Kohlpharma jest kolejnym rozstrzygnięciem Trybunału Sprawiedliwości Unii Europejskiej, które wyznacza ramy prawne działalności polegającej na wprowadzaniu do obrotu produktów leczniczych pochodzących z importu równoległego. Tym samym Trybunał kontynuuje swego rodzaju tradycję orzeczniczą, która polega na tym, że kluczowe aspekty problematyki importu równoległego produktów leczniczych są regulowane na poziomie prawa Unii Europejskiej w drodze rozstrzygnięć mających za przedmiot interpretację art. 34 i 36 Traktatu o funkcjonowaniu Unii Europejskiej (TFUE) i zapadających w konkretnych sprawach kierowanych do Trybunału przez sądy odsyłające państw członkowskich. W komentowanym wyroku Trybunał utrzymał interpretację art. 34 i 36 TFUE, zgodnie z którą powołane przepisy wyłączają stosowanie przepisów krajowych państwa członkowskiego, zgodnie z którymi cofnięcie pozwolenia referencyjnego w kraju importu powoduje automatycznie skutek w postaci wygaśnięcia pozwolenia na import równoległy. Trybunał wyznaczył również bardziej precyzyjne granice wyjątku, zawartego w art. 36 TFUE, dotyczącego ochrony zdrowia i życia ludzi. Orzekł bowiem, że cel w postaci bezpieczeństwa farmakoterapii może być osiągnięty poprzez działania polegające na współdziałaniu właściwych organów państw członkowskich. Komentowany wyrok ma istotne znaczenie dla oceny zgodności z prawem Unii

CORRESPONDENCE ADDRESS: Jarosław Dudzik, PhD, Assistant Professor, Maria Curie-Skłodowska University (Lublin), Faculty of Law and Administration, Institute of Law, Plac Marii Curie-Skłodowskiej 5, 20-031 Lublin, Poland. 
Europejskiej przepisu art. 21a ust. 3a ustawy Prawo farmaceutyczne. W świetle stanowiska Trybunału powołany przepis polskiego prawa należy oceniać jako nadmierne ograniczenie swobody przepływu towarów.

Slowa kluczowe: import równoległy; produkty lecznicze; swoboda przepływu towarów; prawo Unii Europejskiej; ochrona zdrowia i życia ludzi; przepływ towarów; bezpieczeństwo farmakoterapii

\section{TEZA}

Artykuły 34 i 36 TFUE należy interpretować w ten sposób, że sprzeciwiają się one temu, aby właściwy organ pierwszego państwa członkowskiego odmawiał zatwierdzenia zmian informacji i dokumentów dotyczących produktu leczniczego korzystającego z pozwolenia na dopuszczenie do obrotu w drugim państwie członkowskim i będącego przedmiotem pozwolenia na przywóz równoległy w pierwszym państwie członkowskim z tego tylko powodu, że referencyjne pozwolenie na dopuszczenie do obrotu w pierwszym państwie członkowskim wygasło i że proponowane zmiany opierają się, wraz ze wskazaniami objętymi pozwoleniem w drugim państwie członkowskim dla produktu leczniczego będącego przedmiotem przywozu równoległego, na wskazaniach dotyczących produktu leczniczego mającego to samo wskazanie terapeutyczne, korzystającego z pozwolenia na dopuszczenie do obrotu w obu odnośnych państwach członkowskich i produkowanego zasadniczo z tej samej substancji czynnej, lecz pod inną postacią farmaceutyczną, jeżeli pozwolenie na przywóz równoległy jest nadal ważne i nie istnieje jakakolwiek wystarczająca wskazówka świadcząca o ryzyku dla skutecznej ochrony życia i zdrowia ludzkiego.

\section{STAN FAKTYCZNY SPRAWY}

W wyroku z dnia 8 października 2020 r., wydanym w sprawie C-602/19 Kohlpharma, ${ }^{1}$ Trybunał Sprawiedliwości Unii Europejskiej (dalej: TSUE lub Trybunał) rozpoznał pytania prejudycjalne skierowane, na podstawie art. 267 Traktatu o funkcjonowaniu Unii Europejskiej, ${ }^{2}$ przez Verwaltungsgericht Köln (Sąd Administracyjny w Kolonii, Niemcy) na podstawie postanowienia z dnia 9 lipca 2019 r.

${ }^{1}$ Wyrok TSUE z dnia 8 października 2020 r. w sprawie C-602/19, Kohlpharma GmbH przeciwko Bundesrepublik Deutschland, ECLI:EU:C:2020:804. Tekst polski wyroku jest dostępny na stronie: https://curia.europa.eu/juris/document/document.jsf?text=\&docid=232149\&pageIndex=0\&doclan$\mathrm{g}=\mathrm{PL} \& \operatorname{mode}=1 \mathrm{st} \& \operatorname{dir}=\&$ occ $=$ first\&part $=1 \& \mathrm{cid}=539269$ [dostęp: 10.08 .2021$]$.

2 Traktat o funkcjonowaniu Unii Europejskiej (wersja skonsolidowana) (Dz.Urz. C 326, 26.10.2012, s. 47-390), dalej: TFUE. 
Postanowienie to zostało wydane w ramach postępowania toczącego się przed sądem odsyłającym, które dotyczyło skargi złożonej przez Kohlpharma GmbH, największego obecnie niemieckiego importera równoległego, na decyzję administracyjną wydaną przez organ krajowy - Bundesinstitut für Arzneimittel und Medizinprodukte (Federalny Instytut Produktów Leczniczych i Medycznych, BfArM). ${ }^{3}$

Wydając skarżoną decyzję, BfArM odmówił zatwierdzenia wprowadzonej przez importera równoległego zmiany informacji i dokumentów dotyczących produktu leczniczego o nazwie „Consilium 5 mg” (nazwa we Włoszech - kraju wywo$\mathrm{zu}$ - to „Impromen $5 \mathrm{mg}$ ”), będącego przedmiotem ważnego pozwolenia na import równoległy. Zgodnie z przepisami niemieckiej ustawy o produktach leczniczych (Arzneimittelgesetz, AMG), odmowa udzielenia zgody na zmiany wnioskowane przez importera, wydana na podstawie $\S 29$ ust. 2a niemieckiej AMG, prowadziła do wygaśnięcia pozwolenia na import równoległy produktu leczniczego, pozwolenie miało bowiem charakter warunkowy. Jego ważność była uzależniona od spełnienia przez importera równoległego obowiązku dokonywania aktualizacji dokumentacji, w szczególności ulotek przylekowych, uwzględniających zmiany dotyczące pozwolenia na dopuszczenie do obrotu referencyjnego produktu leczniczego. Okolicznością o kluczowym znaczeniu było to, że pozwolenie na dopuszczenie do obrotu referencyjnego produktu leczniczego „Consilium 5 mg”, mającego postać farmaceutyczną tabletek powlekanych, wygasło wcześniej na skutek wycofania produktu z rynku niemieckiego przez posiadacza pozwolenia. Wobec powyższego BfArM wydał decyzję odmowną w przedmiocie wniosku importera o dokonanie zmian dokumentacji, przyjmując brak możliwości jej dostosowania ze względu na wygaśnięcie pozwolenia referencyjnego.

W uzasadnieniu skargi na decyzję BfArM importer równoległy wskazał, że wnioskowane zmiany dokumentacji produktu leczniczego pochodzącego z importu równoległego „odnoszą się do produktu leczniczego zawierającego tę samą substancję czynną i polegają jedynie na transpozycji na tabletki wskazań dotyczących kropli. Ponadto stosowanie produktu leczniczego w formie tabletek zależy od ich przepisania przez lekarza i stanowi istotną i utrwaloną praktykę zastępczą względem praktyki dla preparatu farmaceutycznego w postaci kropli". ${ }^{4} \mathrm{~W}$ konsekwencji, jak podniósł importer równoległy, decyzja odmowna co do zmiany dokumentacji produktu importowanego stanowi nieuzasadnione ograniczenie importu równoległego. Ze względu na fakt dostępności informacji dotyczących innego, zasadniczo

${ }^{3}$ W strukturze organów krajowych BfArM jest odpowiednikiem polskiego Urzędu Rejestracji Produktów Leczniczych, Wyrobów Medycznych i Produktów Biobójczych. W obszarze importu równoległego obie instytucje zajmują centralne pozycje, wykonując chociażby kompetencję w zakresie dopuszczania do obrotu produktów leczniczych z importu równoległego oraz zatwierdzając następnie jakiekolwiek zmiany dokumentacji takich produktów.

${ }^{4}$ Pkt 17 uzasadnienia wyroku TSUE. 
tożsamego produktu leczniczego ( $\mathrm{tj}$. mającego postać farmaceutyczną kropli, a nie tabletek powlekanych jak w przypadku produktu referencyjnego), organ krajowy może zweryfikować zasadność wnioskowanych zmian i zapewnić w ten sposób bezpieczeństwo farmakoterapii. Importer równoległy wskazał zatem, że nie istnieje mniej restrykcyjny środek, za pomocą którego można zapewnić ochronę zdrowia publicznego, nie ograniczając jednocześnie swobody przepływu towarów.

Rozpoznając skargę na decyzję BfArM, sąd odsyłający uznał, że dla rozstrzygnięcia sprawy było niezbędne skierowanie do TSUE pytań prejudycjalnych na podstawie art. 267 TFUE, dotyczących interpretacji art. 34 i 36 TFUE. Wobec powyższego sąd odsyłający zawiesił postępowanie i skierował do TSUE dwa pytania prejudycjalne o następującym brzmieniu: „1) Czy zgodnie z wyrażoną w art. 34 TFUE zasadą swobody przepływu towarów oraz wypracowanymi na jej podstawie zasadami przywozu równoległego produktów leczniczych dopuszczalne jest wyrażenie przez krajowy organ właściwy w sprawach pozwolenia zgody na zmianę informacji o dawkowaniu produktu leczniczego przywożonego w ramach przywozu równoległego także wtedy, gdy wygasło pozwolenie na dopuszczenie produktu referencyjnego do obrotu, a zmiana uzasadniana jest przejęciem informacji dotyczącej zasadniczo identycznego co do składu krajowego produktu leczniczego o innej postaci farmaceutycznej w połączeniu $z$ informacjami dopuszczonymi przez kraj wywozu dla produktów leczniczych przywożonych w ramach przywozu równoległego? 2) Czy w oparciu o art. 34 i art. 36 TFUE organ krajowy może odmówić wyrażenia zgody na taką zmianę, powołując się na to, że importerzy równolegli są zwolnieni z obowiązku przedkładania okresowych raportów o bezpieczeństwie oraz że wobec braku krajowego pozwolenia na dopuszczenie referencyjnego produktu do obrotu organ nie dysponuje aktualnymi danymi o stosunku korzyści do ryzyka, aktualne pozwolenie krajowe dotyczy produktu leczniczego w innej postaci farmaceutycznej i, w stosunku do pozwolenia dotyczącego tej samej postaci farmaceutycznej produktu leczniczego w kraju wywozu, odnosi się do innej zawartości substancji czynnej, a nadto nie ma możliwości łącznego zawarcia dwóch postaci farmaceutycznych produktu leczniczego w jednym tekście informacyjnym?”.

Odpowiadając na tak sformułowane pytania, TSUE przyjął, że należy je rozpoznawać łącznie. ${ }^{5} \mathrm{~W}$ konsekwencji Trybunał orzekł tak, jak w przedstawionej powyżej tezie wyroku. Jednakże analiza całości omawianego rozstrzygnięcia - tezy wyroku wraz z jego uzasadnieniem - prowadzi do wniosku, że poza samą kwestią, do której Trybunał odniósł się w tezie wyroku, przedmiotem oceny $\mathrm{z}$ jego strony były jeszcze co najmniej dwa istotne zagadnienia prawne, związane $\mathrm{z}$ interpretacją art. 34 i 36 TFUE w kontekście przesłanek i dopuszczalnych ograniczeń importu równoległego. Nie znalazły one odbicia w tezie wyroku, ponieważ Trybunał przyjął, iż pozostają bez znaczenia dla rozstrzygnięcia sądu odsyłającego ze względu na

${ }^{5}$ Pkt 37 uzasadnienia wyroku TSUE. 
szczególne okoliczności prawne i faktyczne konkretnie tej sprawy. Wymieniając te zagadnienia, jako zasługujące na szersze omówienie w niniejszej glosie, należy na pierwszym miejscu wskazać kwestię podstawy prawnej harmonizacji przepisów krajowych dotyczących dopuszczenia do obrotu produktów leczniczych pochodzących z importu równoległego. Trybunał podtrzymał w całości swoje dotychczasowe stanowisko, z którego wynika że kwestia ta pozostaje poza obszarem harmonizacji dyrektywy 2001/83/WE. ${ }^{6}$ Ponadto TSUE odniósł się do kwestii skutków prawnych wygaśnięcia pozwolenia na dopuszczenie do obrotu referencyjnego produktu leczniczego $\mathrm{w}$ odniesieniu do powiązanego z nim pozwolenia na import równoległy tożsamego produktu. Trybunał potwierdził również interpretację przepisów traktatowych o swobodzie przepływu towarów, z której wynika zakaz stosowania regulacji krajowych, przewidujących automatyczne wygaśnięcie w takim przypadku pozwolenia importowego. ${ }^{7}$

\section{PODSTAWA PRAWNA HARMONIZACJI MECHANIZMU DOPUSZCZENIA DO OBROTU PRODUKTÓW LECZNICZYCH Z IMPORTU RÓWNOLEGŁEGO}

W komentowanym wyroku Trybunał stwierdził jasno, że problematyka dopuszczenia do obrotu produktów leczniczych z importu równoległego leży poza obszarem harmonizacji przewidzianej w dyrektywie 2001/83/WE. Uzasadniając to stanowisko, stwierdzono, że powołana dyrektywa „nie może mieć zastosowania do produktu leczniczego, który korzysta z pozwolenia na dopuszczenie do obrotu w jednym państwie członkowskim i którego przywóz do innego państwa członkowskiego stanowi przywóz równoległy względem produktu leczniczego posiadającego już pozwolenie na dopuszczenie do obrotu w tym drugim państwie członkowskim, jako że ów przywożony produkt leczniczy nie może w takim przypadku zostać uznany za wprowadzony po raz pierwszy do obrotu w państwie członkowskim przywozu". ${ }^{8}$

Ponadto Trybunał wskazał, że w przypadku dopuszczenia do obrotu produktów znajdujących się w imporcie równoległym, warunki ich dopuszczenia do obrotu na

${ }^{6}$ Dyrektywa 2001/83/WE Parlamentu Europejskiego i Rady z dnia 6 listopada 2001 r. w sprawie wspólnotowego kodeksu odnoszącego się do produktów leczniczych stosowanych u ludzi (Dz.Urz. L 311/67, 28.11.2001). Skonsolidowany tekst dyrektywy jest dostępny na stronie: https:/eur-lex.europa.eu/ legal-content/PL/TXT/HTML/?uri=CELEX:02001L0083=20190726-\&qid1626079819617=\&fromEN [dostęp: 10.08.2021].

7 Zamiast wielu zob. wyrok TSUE z dnia 8 maja 2003 r. w sprawie C-15/01, Paranova Läkemedel AB i inni przeciwko Läkemedelsverket, ECLI:EU:C:2003:256, Zb.Orz. 2003, s. I-04175.

${ }^{8}$ Pkt 25 wyroku TSUE. Szerzej w tej kwestii: C. Desogus, Competition and Innovation in the EU Regulation of Pharmaceuticals: The Case of Parallel Trade, Cambridge 2011. 
rynku państwa członkowskiego wynikają wprost z art. 34 i 36 TFUE. ${ }^{9}$ Mamy tu zatem do czynienia z sytuacją, która w teorii prawa Unii Europejskiej jest określana jako harmonizacja negatywna prawa krajowego..$^{10}$

Powołując podstawy prawne rozstrzyganej sprawy, Trybunał wskazał jednocześnie, że w odniesieniu do dopuszczonych do obrotu produktów z importu równoległego mają zastosowanie przepisy Tytułu IX „Nadzór na bezpieczeństwem farmakoterapii” dyrektywy 2001/83/WE. Pozwalają one na realizację współpracy państw członkowskich, w szczególności w odniesieniu do oceny zmian w stosunku korzyści do ryzyka produktu leczniczego będącego przedmiotem importu równoległego.

Powołane przepisy Tytułu IX dyrektywy 2001/83/WE nie regulują wprawdzie żadnej procedury, która byłaby ukierunkowana na wymianę informacji między państwami członkowskimi w zakresie produktów leczniczych, objętych zakresem pozwoleń na import równoległy w państwach członkowskich, w tym znaczeniu, że nie ma procedury „dedykowanej” dla tego rodzaju produktów. Jest to jednak o tyle zrozumiałe, że - jak już wskazano - sama kwestia dopuszczenia do obrotu produktów z importu równoległego nie jest objęta zakresem regulacji dyrektywy, a wynika z interpretacji przepisów art. 34-36 TFUE. Tak samo obowiązek współpracy państw członkowskich w zakresie pozyskiwania informacji dotyczących produktów leczniczych znajdujących się $\mathrm{w}$ imporcie równoległym wynika $\mathrm{z}$ interpretacji przepisów prawa pierwotnego. Należy dodać, że przepisy Tytułu IX dyrektywy 2001/83/WE obejmują wszystkie produkty lecznicze dopuszczone do obrotu w państwach członkowskich - niezależnie od tego, w ramach jakiej procedury nastąpiło dopuszczenie do obrotu, tzn. także produkty lecznicze znajdujące się w imporcie równoległym.

\section{ZAKAZ AUTOMATYCZNEGO WYGASZENIA POZWOLEŃ IMPORTOWYCH}

W komentowanym wyroku Trybunał podtrzymał w całości swoje dotychczasowe orzecznictwo dotyczące skutków wygaśnięcia pozwolenia na dopuszczenie do obrotu referencyjnego produktu leczniczego w odniesieniu do powiązanego z nim pozwolenia ,importowego”. Jednocześnie kwestia ta została oceniona przez

${ }^{9}$ Ibidem, wraz z powołanym orzecznictwem TSUE, a w szczególności wyrokiem z dnia 3 lipca 2019 r. w sprawie C-387/18, Delfarma, EU:C:2019:556, pkt 19.

${ }_{10}$ Szeroko w tej kwestii: M. Szpunar, Bezpośredni skutek prawa wspólnotowego: jego istota oraz próba uporządkowania terminologii, „Europejski Przegląd Sądowy” 2005, nr 2, s. 4-17; A. Kunkiel-Kryńska, Metody harmonizacji prawa konsumenckiego w Unii Europejskiej i ich wptyw na procesy implementacyjne w państwach członkowskich, Warszawa 2013. 
TSUE jako nieistotna dla rozstrzygnięcia sporu głównego, ponieważ - jak zauważył Trybunał - prawo niemieckie jest dostosowane w tym zakresie do jego wcześniejszego orzecznictwa wydanego na gruncie art. 34 i 36 TFUE. ${ }^{11}$ Jednakże stanowisko Trybunału co do tych kwestii zasługuje na uwagę w kontekście oceny zgodności z prawem Unii Europejskiej przepisów prawa polskiego, przewidujących wygaśnięcie pozwolenia na import równoległy w razie wygaśnięcia pozwolenia referencyjnego.

W obszernym wywodzie Trybunał podsumował swoje dotychczasowe orzecznictwo w tym zakresie, wskazując je jako punkt wyjścia do analizy zasadniczego zagadnienia wynikającego z pytań sądu odsyłającego. Z wywodu Trybunału wynika jasno, że w dotychczasowej praktyce TSUE była już przedmiotem oceny kwestia zgodności z prawem Unii Europejskiej przepisów krajowych, które przewidywały wygaśnięcie (lub cofnięcie) pozwolenia na import równoległy produktu leczniczego w razie wygaśnięcia pozwolenia referencyjnego w państwie importu. $Z$ jednej strony z orzecznictwa TSUE wynika, że przepisy art. 34 i 36 TFUE wyłączają stosowanie przepisów krajowych państwa członkowskiego, zgodnie z którymi cofnięcie pozwolenia referencyjnego w kraju importu powoduje automatycznie skutek w postaci wygaśnięcia pozwolenia na import równoległy. $Z$ drugiej strony wynika z tych orzeczeń, że w przypadku cofnięcia pozwolenia referencyjnego w państwie importu może to mieć znaczenie dla ważności pozwolenia na import równoległy, jeżeli cofnięcie nastąpiło z przyczyn związanych z ochroną zdrowia publicznego. ${ }^{12}$

Przywołując swoje dotychczasowe orzecznictwo, Trybunał wskazał, że jednym z pierwszych orzeczeń TSUE, dotyczących tej kwestii, był wyrok z dnia 10 września 2002 r. w sprawie C-172/00 Ferring. ${ }^{13}$ Wyrok został wydany przez TSUE w związku ze skierowaniem przez sąd niemiecki wniosku o wydanie wyroku prejudycjalnego na podstawie obecnego art. 267 TFUE (dawniej art. 234 TWE). Sąd krajowy sformułował pytania dotyczące zgodności z przepisami traktatowymi o swobodzie przepływu towarów przepisów krajowych, zgodnie z którymi pozwolenie na import równoległy produktu leczniczego do państwa członkowskiego wygasa na skutek cofnięcia pozwolenia referencyjnego w tym państwie. W odpowiedzi na tak postawione pytanie TSUE udzielił jasnej odpowiedzi, stwierdzając $w$ tezie pierwszej wyroku, iż przepisy art. 28 i 30 TWE (obecnie art. 34 i 36 TFUE) stoją na przeszkodzie przepisom krajowym, zgodnie z którymi cofnięcie pozwolenia na dopuszczenie do obrotu jako takiego, na wniosek jego posiadacza, pociąga za

${ }^{11}$ Zgodnie z przepisami niemieckiej AMG w razie wygaśnięcia pozwolenia na dopuszczenie do obrotu referencyjnego produktu leczniczego, pozwolenie na dopuszczenie do obrotu produktu leczniczego z importu równoległego pozostaje ważne - pkt 34 i 35 wyroku TSUE.

12 Por. M. Roszak, Handel równoległy produktami leczniczymi w prawie unijnym. Granice swobody przepływu towarów na rynku farmaceutycznym, Warszawa 2014.

13 Wyrok TSUE z dnia 10 września 2002 r. w sprawie C-172/00, Ferring Arzneimittel GmbH przeciwko Eurim-Pharm Arzneimittel GmbH, ECLI:EU:C:2002:474, Zb.Orz. 2002, s. I-06891. 
sobą cofnięcie pozwolenia na import równoległy wydanego dla danego produktu leczniczego. ${ }^{14}$

Trybunał podtrzymał to stanowisko w kolejnych wyrokach dotyczących zgodności przepisów krajowych z zasadą swobodnego przepływu towarów. Należy wskazać w szczególności na wyroki TSUE w sprawach C-113/01 Paranova Oy ${ }^{15}$ oraz C-15/01 Paranova Läkemedel. ${ }^{16}$ Uzupełniając wywody Trybunału w tym zakresie, można dodać, że orzecznictwo TSUE w tym zakresie zostało podsumowane w wytycznych Komisji Europejskiej z dnia 31 grudnia 2003 r., ${ }^{17}$ w których Komisja stwierdziła jasno: „The issue arises of when a marketing authorization of reference is withdrawn in the Member State of importation for reasons other than the protection of public health and the imported product continues to be lawfully marketed in the Member State of exportation under the marketing authorization issued in that State. This is the case where, for example, a new version of a medicinal product is marketed in a Member State while the old version continues to be imported from another Member State. The Court has ruled [przypis dolny $20-$ Cases C-172/00 Ferring (2002) ECR I-6891 and C-15/01 Paranova (2003) ECR] that the withdrawal of such a marketing authorization does not mean in itself that the quality, efficacy and safety of the old version are called into question. It has been acknowledged that the competent authorities of the Member State of importation must adopt the measures necessary for the purpose of verifying the quality, efficacy and safety of the old version of the medicinal product and that this objective must nevertheless be attained by measures having a less restrictive effect on the import of medicinal products than the automatic cessation of the validity of the parallel import license. A possible way of attaining such an objective is through cooperation with the national authorities of the other Member States by means of access to the documents and data produced by the manufacturer or other companies in the same group, relating to the old version in the Member States in which that version is still marketed on the basis of a marketing authorization still in force". ${ }^{18}$

W odniesieniu do cytowanych rozstrzygnięć TSUE należy dodatkowo podkreślić, że pojęcie „cofnięcia pozwolenia na dopuszczenie do obrotu” należy inter-

${ }_{14}$ Teza nieprzetłumaczona na język polski: „Article 28 EC and Article 30 EC [obecnie art. 34 i 36 TFUE] preclude national legislation under which the withdrawal, at the request of its holder, of the marketing authorization of reference of itself entails the withdrawal of the parallel import license granted for the medicinal product in question".

${ }^{15}$ Wyrok TSUE z dnia 8 maja 2003 r. w sprawie C-113/01, Paranova Oy, ECLI:EU:C:2003:258, Zb.Orz. 2003, s. I-04243.

16 Wyrok TSUE z dnia 8 maja 2003 r. w sprawie C-15/01, Paranova Läkemedel AB i inni przeciwko Läkemedelsverket.

${ }_{17}$ Commission Communication on parallel imports of proprietary medicinal products for which marketing authorisations have already been granted, $\operatorname{COM}(2003) 839$ final.

${ }^{18}$ Ibidem, s. 8-9. 
pretować szeroko. Obejmuje ono zatem nie tylko sytuację, w której pozwolenie takie jest cofnięte na wniosek uprawnionego, lecz także każdą sytuację, w której pozwolenie traci ważność, niezależnie od tego, czy następuje to na wniosek uprawnionego (rzeczywiste cofnięcie) czy też na skutek zaistnienia innych zdarzeń, a w szczególności wskutek upływu czasu, na który pozwolenie zostało udzielone. ${ }^{19}$

Biorąc powyższe pod uwagę, Trybunał podtrzymał swoją dotychczasową interpretację art. 34 i 36 TFUE. Z jednej strony z tej interpretacji wynika, że powołane przepisy wykluczają co do zasady stosowanie przepisów krajowych państwa członkowskiego, które przewidują, iż wygaśnięcie pozwolenia referencyjnego na dopuszczenie do obrotu w tym państwie produktu leczniczego stanowi wystarczającą i wyłączną przesłankę do stwierdzenia wygaśnięcia pozwolenia na import równoległy do tego państwa produktu leczniczego. Z drugiej strony powołane przepisy TFUE nie stoją na przeszkodzie regulacjom krajowym, które przewidują stwierdzenie wygaśnięcia pozwolenia na import równoległy, jeżeli jest to uzasadnione szczególnymi, dodatkowymi okolicznościami stanu faktycznego konkretnej sprawy, nie zaś samym faktem wygaśnięcia pozwolenia referencyjnego. Przykładowo dotyczy to sytuacji, kiedy pozwolenie referencyjne zostało cofnięte ze względu na zagrożenie dla życia i zdrowia ludzi (tj. zdrowia publicznego). Zastosowanie przepisu krajowego w takim przypadku wymaga każdorazowo ustalenia przez organ krajowy co najmniej przyczyn wygaśnięcia/cofnięcia pozwolenia referencyjnego.

Powołane stanowisko Trybunału, podtrzymane w komentowanym wyroku, ma istotne znaczenie dla oceny zgodności przepisów ustawy Prawo farmaceutyczne $^{20} \mathrm{z}$ prawem Unii Europejskiej. Przepisy polskiej ustawy wymagają nie tylko tego, aby pozwolenie referencyjne obowiązywało $\mathrm{w}$ dacie rozpoznawania wniosku o udzielenie pozwolenia na dopuszczenie do obrotu produktu z importu równoległego. ${ }^{21}$ Przepis art. 21a ust. 3a PrFarm uzależnia istnienie pozwolenia na import równoległy produktu leczniczego od istnienia referencyjnego pozwolenia na dopuszczenie do obrotu produktu leczniczego. Zachodzi zatem zależność polegająca na tym, że raz udzielone pozwolenie na import równoległy jest permanentnie powiązane z pozwoleniem referencyjnym. Wynika to jasno z brzmienia powołanego przepisu art. 21a ust. 3a PrFarm. Stwierdza on w sposób jasny i niepodlegający interpretacji, że „pozwolenie na import równoległy wygasa po upływie roku od

19 Taką interpretację przedmiotowych wyroków przyjęła Komisja Europejska w cytowanych wyżej wytycznych z dnia 31 grudnia 2003 r. Ze względu na znaczenie dla przedmiotu opinii należy powołać in extenso następujący fragment tego dokumentu (s. 9, in fine): „It may reasonably be assumed that the same principles apply when the reference marketing authorization of a medicinal product is still valid in the Member State of exportation but is left to expire in the member State of importation so that a new version is marketed".

${ }^{20}$ Ustawa z dnia 6 września 2001 r. - Prawo farmaceutyczne (t.j. Dz.U. poz. 974, 28.05.2021), dalej: PrFarm.

${ }^{21}$ Przepis art. 2 pkt $7 \mathrm{~b}$ lit. a i b PrFarm. 
dnia wygaśnięcia pozwolenia na dopuszczenie do obrotu na terytorium Rzeczypospolitej Polskiej”. Wynika to także z praktyki stosowania art. 21a ust. 3a PrFarm przez Prezesa Urzędu Rejestracji Produktów Leczniczych, Wyrobów Medycznych i Produktów Biobójczych. ${ }^{22}$

Z powyższego wynika, że art. 21a ust. 3a PrFarm jest stosowany w taki sposób, że jedyną i wystarczającą przesłanką do stwierdzenia wygaśnięcia pozwolenia na dopuszczenie do obrotu produktu z importu równoległego jest wygaśnięcie pozwolenia referencyjnego. W toku stosowania art. 21a ust. 3a PrFarm nie bierze się pod uwagę innych okoliczności, w szczególności tych dotyczących przyczyn wygaśnięcia pozwolenia referencyjnego. Nie ma przy tym znaczenia fakt, że wygaśnięcie pozwolenia na dopuszczenie do obrotu produktu z importu równoległego następuje z upływem roku, a nie natychmiast wraz z wygaśnieciem pozwolenia referencyjnego. Nie zmienia to bowiem w niczym oceny w zakresie przyczyn czy też przesłanek wygaśnięcia pierwszego ze wskazanych pozwoleń.

Mając na uwadze utrwalone orzecznictwo TSUE, podsumowane w pkt 28-33 komentowanego wyroku, krajowy przepis - taki jak art. 21a ust. 3a PrFarm - musi być oceniany jako sprzeczny z art. 34 i 36 TFUE. ${ }^{23}$ Zgodnie z zawartą $\mathrm{w}$ tym przepisie normą prawną pozwolenie na import równoległy produktu leczniczego wygasa bowiem automatycznie ze względu na wygaśnięcie pozwolenia referencyjnego. Ponadto powołany przepis nie przewiduje, aby organ wydający decyzję w przedmiocie pozwolenia na import równoległy ustalał przyczyny wygaśnięcia pozwolenia referencyjnego, a co za tym idzie oceniał celowość wygaśnięcia pozwolenia importowego ze względu na ochronę zdrowia publicznego. Praktyka stosowania art. 21a ust. 3a PrFarm pokazuje, że kwestia uzasadnienia ochroną zdrowia publicznego nie podlega ocenie ze strony organu. Brak jest zatem możliwości usprawiedliwienia takiej regulacji prawa krajowego na gruncie art. 36 TFUE. ${ }^{24}$

Do takich samych wniosków prowadzi ocena praktyki Urzędu Rejestracji Produktów Leczniczych, Wyrobów Medycznych i Produktów Biobójczych dotyczącej przedłużania pozwoleń na dopuszczenie do obrotu produktów leczniczych

${ }^{22}$ Przykładowo w decyzji z dnia 24 września 2019 r. Prezes Urzędu przyją: „Wygaśnięcie z dniem 25 września 2018 r. pozwolenia na dopuszczenie do obrotu nr ... na terytorium Rzeczypospolitej Polskiej stanowi, zgodnie z art. 21a ust. 3a ustawy z dnia 6 września 2001 r. - Prawo farmaceutyczne, przesłankę do stwierdzenia wygaśnięcia pozwolenia na import równoległy $\mathrm{nr}$ 8/11 na podstawie powołanego powyżej art. $162 \S 1$ pkt 1 w zw. z art. $162 \S 3$ ustawy z dnia 14 czerwca 1960 r. - Kodeks postępowania administracyjnego". Tak samo przyjął organ w decyzji powtórnej w tej samej sprawie z dnia 18 listopada 2019 r., nr UR/UD/0001/19/IR, s. 2.

${ }_{23}$ Tak również M. Kondrat, [w:] Prawo farmaceutyczne. Komentarz, red. M. Kondrat, Warszawa 2016, s. 344-345, 353; Prawo farmaceutyczne. Komentarz, red. W.L. Olszewski, Warszawa 2016.

${ }^{24}$ Kwestia zgodności art. 21a ust. 3a PrFarm z art. 34 i 36 TFUE jest obecnie przedmiotem oceny TSUE w postępowaniu prejudycjalnym w sprawie C-488/20 Delfarma. Postępowanie dotyczy pytań prejudycjalnych sformułowanych przez Wojewódzki Sąd Administracyjny w Warszawie w postanowieniu z dnia 9 września 2020 r., VI SA/Wa 235/20. 
z importu równoległego. Z obserwacji dotychczasowej praktyki Urzędu wynika, że w sytuacji wygaśnięcia pozwolenia referencyjnego wnioski o przedłużenie już udzielonych pozwoleń importowych spotykają się z decyzją odmowną, przy czym również $\mathrm{w}$ tych sytuacjach podstawą odmowy jest wyłącznie fakt wygaśnięcia pozwolenia referencyjnego, bez odwołania się do oceny z punktu widzenia rzeczywistych zagrożeń dla zdrowia publicznego.

\section{WYMÓG PROPORCJONALNOŚCI ŚRODKÓW KRAJOWYCH UZASADNIONYCH OCHRONĄ ZDROWIA PUBLICZNEGO}

Jak się wydaje, punkt ciężkości oceny Trybunału w komentowanej sprawie dotyczył kwestii objętej zakresem pytania drugiego sądu odsyłającego. Dotyczyło ono oceny, czy praktyka krajowa może być uzasadniona na podstawie art. 36 TFUE ze względu fakt, że importerzy równolegli są zwolnieni z obowiązku przedkładania okresowych raportów o bezpieczeństwie, a wobec braku krajowego pozwolenia na dopuszczenie referencyjnego produktu do obrotu organ krajowy nie dysponuje aktualnymi danymi o stosunku korzyści do ryzyka.

Oceniając trafność komentowanego rozstrzygnięcia Trybunału co do tej kwestii, należy wskazać, że w świetle utrwalonego orzecznictwa TSUE nie budzi wątpliwości, iż zgodnie z art. 36 TFUE wymóg ochrony zdrowia może uzasadniać środki ograniczające swobodny przepływ produktów leczniczych między państwami członkowskimi. Zgodnie z ugruntowanym orzecznictwem Trybunału zdrowie i życie ludzi mają pierwszorzędne znaczenie pośród dóbr i interesów chronionych TFUE, a do państw członkowskich należy decyzja o poziomie, na jakim chcą zapewnić ochronę zdrowia publicznego oraz o sposobie osiągnięcia tego poziomu. ${ }^{25}$

$Z$ orzecznictwa Trybunału wynika jednak również, że zasada proporcjonalności, która stanowi podstawę ostatniego zdania art. 36 TFUE, wymaga, aby uprawnienie państw członkowskich do zakazania lub ograniczenia przywozu produktów pochodzących z innych państw członkowskich było ograniczone do tego, co jest konieczne do osiągnięcia zamierzonych zgodnie z prawem celów ochrony zdrowia. W związku z tym uregulowanie lub praktyka krajowa nie mogą korzystać z odstępstwa przewidzianego w art. 36 TFUE, jeżeli zdrowie i życie ludzi mogą być chronione w równie skuteczny sposób za pomocą środków w mniejszym stopniu ograniczających wymianę handlową w ramach rynku wewnętrznego. W związku z powyższym w kontekście obowiązków organów krajowych w ramach postępowania o udzielenie pozwolenia na import równoległy Trybunał m.in. stwierdził,

${ }^{25}$ Zamiast wielu zob. wyrok TSUE z dnia 20 maja 1976 r. w sprawie 104/75, De Peijper, EU:C:1976:67, pkt 15; wyrok TSUE z dnia 19 października 2016 r. w sprawie C-148/15, Deutsche Parkinson Vereinigung, EU:C:2016:776, pkt 30. 
że właściwe władze narodowe muszą oprzeć swoją decyzję na możliwie najpełniejszych danych, korzystając również z informacji im dostępnych albo tych, które mogą uzyskać w drodze współpracy z władzami narodowymi innych państw członkowskich. ${ }^{26}$ Tym samym jako zbyt daleko idące uznano wymogi wynikające z przepisów krajowych, zgodnie z którymi to podmiot indywidualny powinien dostarczyć organowi wymagane informacje ${ }^{27}$.

W komentowanym wyroku Trybunał podtrzymał w całości dotychczasowe stanowisko. Wskazał, że w celu zapewnienia bezpieczeństwa farmakoterapii państwo członkowskie może podjąć co najmniej dwa rodzaje działań, które umożliwiają pozyskanie aktualnych danych niezbędnych do oceny stosunku korzyści do ryzyka.

Po pierwsze, powołując się na swój wcześniejszy wyrok w sprawie C-172/00 Ferring, Trybunał przyjął, że państwo członkowskie może, w braku ważnego referencyjnego pozwolenia na dopuszczenie do obrotu, zapewnić odpowiedni nadzór nad bezpieczeństwem farmakoterapii, współpracując z władzami krajowymi innych państw członkowskich poprzez dostęp do dokumentów i danych przedstawionych przez producenta dla tego produktu leczniczego w państwach członkowskich, w których jest on nadal sprzedawany na podstawie ważnego pozwolenia na dopuszczenie do obrotu. ${ }^{28}$

Po drugie, jak przyjął Trybunał w tezie komentowanego wyroku, w przypadku braku ważnego referencyjnego pozwolenia na dopuszczenie do obrotu państwo członkowskie może zapewnić odpowiedni nadzór nad bezpieczeństwem farmakoterapii poprzez dostęp do dokumentów i danych dotyczących także innego produktu leczniczego, mającego to samo wskazanie terapeutyczne, korzystającego nadal z pozwolenia na dopuszczenie do obrotu w tym państwie członkowskim i produkowanego zasadniczo z tej samej substancji czynnej, lecz pod inną postacią farmaceutyczną.

Jak wynika z komentowanego wyroku Trybunału, w sytuacji wygaśnięcia pozwolenia bazowego państwo członkowskie może zapewnić ochronę zdrowia publicznego poprzez odpowiedni nadzór nad bezpieczeństwem farmakoterapii nie tylko poprzez dostęp do dokumentów i danych pozyskiwanych we współpracy z właściwymi organami innych państw członkowskich, w których produkt jest nadal sprzedawany, lecz również poprzez dostęp do danych dotyczących zasadniczo tożsamych produktów leczniczych, korzystających nadal z pozwolenia na dopuszczenie do obrotu w tym państwie.

${ }^{26}$ Wyrok TSUE z dnia 1 kwietnia 2004 r. w sprawie C-112/02, Kohlpharma GmbH przeciwko Bundesrepublik Deutschland, Zb.Orz. 2004, s. I-3369, pkt 19-20.

27 J.S. Venit, S. Rey, Parallel Trade and Pharmaceuticals: A Policy in Search of Itself, "European Law Review” 2004, no. 29.

${ }^{28}$ Wyrok TSUE z dnia 10 września 2002 r. w sprawie C-172/00, Ferring Arzneimittel GmbH przeciwko Eurim-Pharm Arzneimittel GmbH, pkt 38 wraz z przytoczonym tam orzecznictwem. 
Stanowisko Trybunału w tym zakresie jest zgodne z intencją prawodawcy unijnego wyrażoną w toku ostatniej, gruntownej nowelizacji przepisów Tytułu IX dyrektywy 2001/83/WE. Nowelizacja ta miała miejsce w następstwie wejścia w życie dyrektywy Parlamentu Europejskiego i Rady 2010/84/UE z dnia 15 grudnia 2010 r. ${ }^{29}$ Miała ona w szczególności na celu wprowadzenie do dyrektywy 2001/83/WE mechanizmów wymiany i udostępniania informacji przez państwa członkowskie, zapewniających ponadnarodowy nadzór nad bezpieczeństwem farmakoterapii. Zgodnie z motywem 4 preambuły dyrektywy 2010/84/UE wprowadzenie zharmonizowanych mechanizmów było podyktowane tym, że „,przepisy dotyczące produktów leczniczych powinny mieć za nadrzędny cel ochronę zdrowia publicznego. Cel ten powinien jednak zostać osiągnięty sposobami niehamującymi swobodnego przepływu bezpiecznych produktów leczniczych wewnątrz Unii. Ocena unijnego systemu nadzoru nad bezpieczeństwem farmakoterapii wykazała, że rozbieżne działania państw członkowskich dotyczące bezpieczeństwa w zakresie produktów leczniczych tworzą przeszkody dla swobodnego przepływu produktów leczniczych. W celu zapobieżenia tym przeszkodom lub ich usunięcia należy wzmocnić i zracjonalizować obowiązujące przepisy w zakresie nadzoru nad bezpieczeństwem farmakoterapii na poziomie unijnym".

Dążąc do realizacji tak określonego celu, w Tytule IX dyrektywy 2001/83/WE uwzględniono szereg mechanizmów wymiany i udostępniania informacji, które pozwalają na ułatwienie współpracy państw członkowskich w zakresie zapewnienia bezpieczeństwa farmakoterapii. Można tu przykładowo wymienić: obowiązek stworzenia i prowadzenia krajowej strony internetowej (art. 106 dyrektywy); obowiązek informowania się nawzajem przez państwa członkowskie, Agencję (EMA) i Komisję o obawach w zakresie nadzoru nad bezpieczeństwem farmakoterapii (art. 106a ust. 2 dyrektywy); obowiązek przekazywania przez państwa członkowskie zgłoszeń działań niepożądanych do bazy Eudravigilance (art. 107a ust. 4 i 5 dyrektywy); obowiązek udostępniania przez Agencję (EMA) państwom członkowskim okresowo aktualizowanych sprawozdań dotyczących bezpieczeństwa, przekazywanych przez posiadaczy pozwolenia na dopuszczenie do obrotu (art. 107b ust. 2 dyrektywy); obowiązek podejmowania przez właściwe organy państw członkowskich wspólnie z Agencją (EMA) działań polegających na monitorowaniu danych w bazie danych Eudravigilance w celu ustalania występowania nowych lub zmienionych rodzajów ryzyka oraz ich wpływu na równowagę ryzyko-korzyść (art. 107h ust. 1 lit. c dyrektywy). ${ }^{30}$

${ }^{29}$ Dyrektywa Parlamentu Europejskiego i Rady 2010/84/UE z dnia 15 grudnia 2010 r. zmieniająca - w zakresie nadzoru nad bezpieczeństwem farmakoterapii - dyrektywę 2001/83/WE w sprawie wspólnotowego kodeksu odnoszącego się do produktów leczniczych stosowanych u ludzi (tekst mający znaczenie dla EOG) (Dz.Urz. L 348/74, 31.12.2010).

${ }^{30} \mathrm{Na}$ gruncie poprzednio obowiązującego stanu prawnego, sprzed harmonizacji dyrektywą 2010/84/UE, także istniały procedury i mechanizmy zapewniające bezpieczeństwo produktów lecz- 
Mając powyższe na uwadze, należy uznać, że Trybunał trafnie przyjął stanowisko o braku proporcjonalności środka krajowego, polegającego na odmowie zgody na aktualizację materiałów dotyczących produktu leczniczego pochodzącego z importu równoległego. Zakładany cel w postaci ochrony zdrowia i życia ludzi, poprzez zapewnienie bezpieczeństwa farmakoterapii, może być bowiem osiągnięty za pomocą środków w mniejszym stopniu ograniczających swobodę przepływu towarów, przewidzianych w przepisach harmonizujących dyrektywy 2001/83/WE.

\section{PODSUMOWANIE}

Wyrok w sprawie C-602/19 Kohlpharma jest kolejnym rozstrzygnięciem Trybunału, które wyznacza ramy prawne działalności polegającej na wprowadzaniu do obrotu produktów leczniczych pochodzących z importu równoległego. Tym samym Trybunał kontynuuje swego rodzaju tradycję orzeczniczą, która polega na tym, że kluczowe aspekty problematyki importu równoległego produktów leczniczych są regulowane na poziomie prawa Unii Europejskiej w drodze rozstrzygnięć mających za przedmiot interpretację art. 34 i 36 TFUE i zapadających w konkretnych sprawach kierowanych do Trybunału przez sądy odsyłające państw członkowskich ${ }^{31}$.

Nie kwestionując zasadności i trafności komentowanego wyroku, wydaje się, że kontynowanie tej metody harmonizacji przepisów państw członkowskich nie jest już wystarczające. Wysoki stopień skomplikowania problematyki obrotu produktami leczniczymi oraz już znaczna liczba wyroków TSUE, wydanych w tym obszarze, utrudniają niekiedy uczestnikom obrotu orientację co do stanu prawnego. Ponadto metoda ta nie jest chyba wystarczająco efektywna, jeżeli wziąć pod uwagę, iż - pomimo upływu czasu od daty wydania przez Trybunał jego kluczowych wyroków w tym obszarze - w dalszym ciągu mamy do czynienia z obowiązywaniem przepisów krajowych, które - tak jak art. 21a ust. 3a PrFarm - stanowią dosyć oczywiste naruszenie art. 34 i 36 TFUE w interpretacji przyjętej przez Trybunał.

Zasadny wydaje się zatem postulat, aby orzecznictwo TSUE, wydane w obszarze warunków obrotu produktami leczniczymi z importu równoległego, doczekało się kodyfikacji w przepisach dyrektywy 2001/83/WE. Nie ulega również wątpliwości, iż zachodzi potrzeba nowelizacji przepisów prawa polskiego w omawianym zakresie. Minimalny zakres postulowanej nowelizacji powinien obejmować

niczych. Por. M. Ożóg, System handlu produktem leczniczym i produktami leczniczymi. Problematyka prawna, Warszawa 2010, s. 230 i n.

${ }^{31} \mathrm{~W}$ odniesieniu do ograniczeń importu równoległego produktów leczniczych, wynikających z praw własności intelektualnej, por. R. Skubisz, Wyczerpanie prawa ochronnego na znak towarowy, [w:] System Prawa Prywatnego, t. 14b: Prawo własności przemysłowej, red. R. Skubisz, Warszawa 2017; Intellectual Property Exhaustion and Parallel Imports, eds. I. Calboli, E. Lee, ECheltenham 2016. 
wykreślenie art. 21a ust. 3a PrFarm lub co najmniej daleko idącą modyfikację tego przepisu, zakładającą wymóg oceny podstaw wygaśnięcia pozwolenia bazowego na wprowadzanie do obrotu produktu leczniczego przed wydaniem decyzji o wygaśnięciu pozwolenia na import równoległy.

\section{BIBLIOGRAFIA}

\section{Literatura}

Desogus C., Competition and Innovation in the EU Regulation of Pharmaceuticals: The Case of Parallel Trade, Cambridge 2011.

Intellectual Property Exhaustion and Parallel Imports, eds. I. Calboli, E. Lee, ECheltenham 2016.

Kondrat M., [w:] Prawo farmaceutyczne. Komentarz, red. M. Kondrat, Warszawa 2016.

Kunkiel-Kryńska A., Metody harmonizacji prawa konsumenckiego w Unii Europejskiej i ich wpływ na procesy implementacyjne w państwach członkowskich, Warszawa 2013.

Ożóg M., System handlu produktem leczniczym i produktami leczniczymi. Problematyka prawna, Warszawa 2010.

Prawo farmaceutyczne. Komentarz, red. W.L. Olszewski, Warszawa 2016.

Roszak M., Handel równoległy produktami leczniczymi w prawie unijnym. Granice swobody przeptywu towarów na rynku farmaceutycznym, Warszawa 2014.

Skubisz R., Wyczerpanie prawa ochronnego na znak towarowy, [w:] System Prawa Prywatnego, t. 14b: Prawo własności przemystowej, red. R. Skubisz, Warszawa 2017.

Szpunar M., Bezpośredni skutek prawa wspólnotowego: jego istota oraz próba uporządkowania terminologii, „Europejski Przegląd Sądowy” 2005, nr 2.

Venit J.S., Rey S., Parallel Trade and Pharmaceuticals: A Policy in Search of Itself, "European Law Review” 2004, no. 29.

\section{Akty prawne}

Commission Communication on parallel imports of proprietary medicinal products for which marketing authorisations have already been granted, $\operatorname{COM}(2003) 839$ final.

Dyrektywa 2001/83/WE Parlamentu Europejskiego i Rady z dnia 6 listopada 2001 r. w sprawie wspólnotowego kodeksu odnoszącego się do produktów leczniczych stosowanych u ludzi (Dz Urz. L 311/67, 28.11.2001).

Dyrektywa Parlamentu Europejskiego i Rady 2010/84/UE z dnia 15 grudnia 2010 r. zmieniająca w zakresie nadzoru nad bezpieczeństwem farmakoterapii - dyrektywę 2001/83/WE w sprawie wspólnotowego kodeksu odnoszącego się do produktów leczniczych stosowanych u ludzi (tekst mający znaczenie dla EOG) (Dz.Urz. L 348/74, 31.12.2010).

Traktat o funkcjonowaniu Unii Europejskiej (wersja skonsolidowana) (Dz.Urz. C 326, 26.10.2012, s. 47-390).

Ustawa z dnia 6 września 2001 r. - Prawo farmaceutyczne (t.j. Dz.U. poz. 974, 28.05.2021).

\section{Orzecznictwo}

Postanowienie WSA w Warszawie w postanowieniu z dnia 9 września 2020 r., VI SA/Wa 235/20.

Wyrok TSUE z dnia 20 maja 1976 r. w sprawie 104/75, De Peijper, EU:C:1976:67. 
Wyrok TSUE z dnia 10 września 2002 r. w sprawie C-172/00, Ferring Arzneimittel GmbH przeciwko Eurim-Pharm Arzneimittel GmbH, ECLI:EU:C:2002:474.

Wyrok TSUE z dnia 8 maja 2003 r. w sprawie C-113/01, Paranova Oy, ECLI:EU:C:2003:258.

Wyrok TSUE z dnia 8 maja 2003 r. w sprawie C-15/01, Paranova Läkemedel AB i inni przeciwko Läkemedelsverket, ECLI:EU:C:2003:256.

Wyrok TSUE z dnia 1 kwietnia 2004 r. w sprawie C-112/02, Kohlpharma GmbH przeciwko Bundesrepublik Deutschland, Zb.Orz. 2004, s. I-3369.

Wyrok TSUE z dnia 19 października 2016 r. w sprawie C 148/15, Deutsche Parkinson Vereinigung, EU:C:2016:776.

Wyrok TSUE z dnia 3 lipca 2019 r. w sprawie C-387/18, Deulfarma, EU:C:2019:556.

Wyrok TSUE z dnia 8 października 2020 r. w sprawie C-602/19, Kohlpharma GmbH przeciwko Bundesrepublik Deutschland, ECLI:EU:C:2020:804.

\section{ABSTRACT}

The judgement in case C-602/19 Kohlpharma is another decision of the Court of Justice of the European Union, which sets legal framework for marketing medicinal products from parallel import. By doing so, the Court continues the adjudicative tradition whereby key aspects of the issue of parallel imports of medicinal products are regulated at the level of EU law through rulings that interpret Articles 34 and 36 of the Treaty on the Functioning of the European Union (TFEU), issued in specific cases referred to the Court by the referring courts of the Member States. In the commented judgement, the Court upheld the interpretation of Articles 34 and 36 TFEU, according to which these provisions exclude the application of national regulations of a Member State, according to which the withdrawal of a reference authorisation in the importing country automatically results in the expiration of the parallel import licence. The Court also defined more precise limits to the exception contained in Article 36 TFEU concerning the protection of human health and life. This is so because it ruled that the objective of pharmacovigilance may be achieved through actions consisting in the cooperation of the competent authorities of the Member States. The commented judgement is of key importance for the assessment of compliance of Article 21a (3a) of the Polish Act - Pharmaceutical Law with the EU law. In the light of the position of the Court, this provision of the Polish law should be assessed as an excessive restriction on the freedom of movement of goods.

Keywords: parallel import; medicinal products; freedom of movement of goods; EU law; protection of human health and life; public health; movement of goods; pharmacovigilance 